\title{
The Mechanisms of Social Illusions and Their Development
}

\author{
Liudmila Viktorovna Shukshina ${ }^{1}$, Olga Viktorovna Mizonova ${ }^{1}$, Evgeny Vladimirovich Motchalov $^{1}$ \& Mikhail \\ Aleksandrovich Eldin ${ }^{1}$ \\ ${ }^{1}$ Ogarev Mordovia State University, Saransk, Republic of Mordovia, Russia \\ Correspondence: Liudmila Viktorovna Shukshina, St. Bolshevik, d. 68, Saransk, Republic of Mordovia, 430005, \\ Russia.
}

$\begin{array}{lc}\text { Received: February 28, } 2015 & \text { Accepted: March 20, } 2015 \quad \text { Online Published: April 26, } 2015 \\ \text { doi:10.5539/res.v7n6p282 } & \text { URL: http://dx.doi.org/10.5539/res.v7n6p282 }\end{array}$

\begin{abstract}
The aim of present article is to study the phenomenon of social illusions and mechanisms of their development. Illusions are defined by the society and transformed by constantly changing social and cultural environment; each time period presents new angles of illusions manifestation. The significance of philosophic understanding of this phenomenon is related to the urge of understanding the society, reality, crisis of identity in modern community, search of the "Self", constantly changing social and cultural situation, behavior and values. The central aim of present study is to describe the mechanisms of social illusions development. The authors of this article attempt to define and describe conscious and unconscious mechanisms of social illusions.
\end{abstract}

Keywords: social illusions, mechanisms, value of social illusions, space of social illusions, conscious and unconscious mechanisms of social illusions

\section{Introduction}

The analysis of the literature shows that the problem of studying social illusions was explored by scientists, such as Plato, Aristotle, Augustine of Hippo, T. Campanella, F. Bacon, I. Kant, G. W. F. Hegel. The questions of social illusions are also addressed by Russian philosophers, e.g., N. A. Berdyaev, N. Y. Grot, N. A. Dobrolyubov, S. L. Frank, as well as by existentialists, like A. Camus, S. Kierkegaard, G. Marcel, J.-P. Sartre, M. Heidegger, A. Schopenhauer, K. Jaspers, and contemporary authors-F. Garifullin, A. V. Kurpatov, V. H. Belenkiy, etc.

The phenomenon of social illusions is thoroughly studied by many international authors. For example, Barelds Dick P. H.; Dijkstra (Barelds \& Dijkstra, 2011, pp. 37-43) analyze positive illusions about the personality of a significant other and their effect on the quality of the relationship. Fletcher, Garth J. O.; Kerr, Patrick S. G. (Fletcher \& Kerr, 2010, pp. 627-658), studying romantic relationships, note that love paradox are usually based on illusions. Snook Brent; Cullen Richard M.; Bernell Craig; et al.(Snook et al., 2008, pp. 1257-1276) focus on illusions about criminologists, the contents of which are mostly determined by their professional activity. The authors suggest, that criminologists can predict the nature of a crime by the crime scene. Such prediction might be an illusion, which occurs, according to the authors, from the ongoing conversations and discussions. Another important aspect of social illusions is studyed by Mersado Alexis; Peters Maarten J. V., Horselenberg Robert; Jelicic Marko; et al. The authors explore social inclusions and social illusions. Separate aspects of illusions are presented in the studies of Heine Steven J., Buchtel Emma E. (Heine \& Buchtel, 2009, pp. 369-394).

Since the time when philosophers, psychologists and historians began to think about the nature of certain social phenomena, they also came to the question about the mechanisms of the development of those phenomena. We define the mechanism as "a system of motions or events, as well as a device, which is used for these motions". According to Kant, "without taking the mechanism of nature as a basic hypothesis of the study, the true knowledge of nature is impossible" (Gubskiy et al., 2009, p. 206).

\section{Methods}

Based on the analysis of the scientific literature, we hypothesize that the mechanisms, underlying social illusions, may be conscious as well as unconscious. We suggest that conscious mechanisms include daydream and fantasy, while the unconscious mechanisms are a number of defense mechanisms-mechanisms of repression, identification, introjection, self-restriction, rationalization, idealisation, projection and transference. We will attempt to describe them. In most cases social illusions have defensive, adaptive or displacing functions, thus providing the personality adaptation to the frustrating situations and creating an illusion of comfort and 
satisfaction.

\section{Results and Discussion}

One of the main mechanisms of social illusions development is repression, which can manifest either separately or in interaction with a system of other mechanisms, underlying social illusions.

Repression is commonly included in the unconscious defense mechanisms, which means that not only does it keep a certain psychological contents from reaching the conscience, but its activity itself remains hidden from the conscious actions.

Repression is a function of the Ego, and it includes several processes:

- Primitive repression, which blocks primitive forbidden impulses and keeps them from reaching the conscience;

- Primary repression, which removes the psychological contents, that causes anxiety, from the conscience and prevents its further appearance;

- Secondary repression, which suppresses the elements that might remind of something previously blocked. Thus, the repressed contents actively continues exist, but, due to the repression and inhibition, in the shape of an illusion (Raygorodskiy, 2006, p. 656).

- Thus, we suggest, that the mechanism of repression is the basis and a prototype of other mechanisms, underlying the development of different groups of social illusions.

- We define identification as an emotional and cognitive mechanism of social illusions. It is an unconscious mechanism of "identifying oneself with another subject, group or sample. It is a mechanism, which allows a person to incorporate the qualities of another person, and change oneself, party or fully, according to the set example" (Gubskiy et al., p. 433).

- The mechanism of identification in social illusions develops through social media, publicity, fiction literature and television. Identification leads to various behavioral consequences, such as mimicking the actions and feelings of the subject, and internalizing his values and affirmations. Considering the multi-functionality of identification, it is necessary to point out, that this mechanism of social illusions plays a very significant role in their occurrence and development. This important mechanism is a phenomenon of subjective assimilation, connecting to the social events, which affect the self-representation of an individual. Identification helps the development of social illusions and, consequently, the ability to adapt other people's opinions, to become less resistant to suggestive influence and more obedient. However, S. Freud separated identification and imitation, psychological contagion, which are based on suggestion and external influences (Freud, 1992, p. 127). Identification appears because of the influence of internal psychological forces. It is possible to identify with the loved one, which can cause an illusion of a mutual love. It is also possible to identify with an enemy, who scares the person; the victim can identify with the abuser. Such situations occurred during the times of mass terror (e.g., in USSR and Germany). In these cases, identification helps to create an illusion of understanding, which relieves anxiety and fear. It is also possible to identify with a great, significant personality, which leads to an illusion of complete understanding and availability and an illusion of inadequate perception, that can further influence the development of individual personality and turn into megalomania in case of pathological development (Sokolov, 1999).

- As a mechanism of social illusions, identification allows to take the roles of others, which, in our opinion, creates selective suggestiveness and conformity. Identification has two opposing tendencies and thus, inner controversies. Firstly, subject A, identifying himself with personality B, thus approves of its existence, often feels love towards it, imitates it; secondly, along with this approving tendency, identification frequently contains a strong tendency to replace the object of compassionate identification, imitation and admiration with the person's own self. However, this tendency to replace the other in his main role, which the person identified with, is negative and contains open or passive aggression.

In everyday life such internal controversy and ambivalence of identification can manifest in very different and often casual ways. For example, many politicians start their career from identification with a certain personality, which has already reached success, thus creating an illusion of an image or an illusion of false recognition. While the young politician admires his role model or even becomes his assistant, he also begins to compete with him either openly or indirectly. Moreover, because the identification still continues, when the winner takes a place of the role model, he does not stop to admire him and - if the winner is really smart—begins to study the reasons of his successes and defeats, his biography (Raygorodskiy, 2006, p. 232). 
On a lesser scale these complex and mostly unconscious processes occur in family relationships between father and son, mother and daughter, in working groups between the group leader and his subordinates.

It is known, that person's judgment of others are often controversial: the person can criticize and praise somebody at the same time. This controversial attitude is, first of all, determined by the fact that not all of the attributed to that person's qualities, both real and imaginary, are valuable and appropriate for the imitation in the opinion the identification subject. The other and stronger reason of this controversy is the ambivalence of identification, the mixture of approval with disapproval, love with hate and envy. Because, while identifying with the other, the person desires to take the other's place, he perceives the other as an obstacle on the way, which the other himself demonstrated by his successful activity.

Another important mechanism, underlying the development of social illusions, is introjection, which is usually studied in relation to identification. S. Freud describes a type of identification, during which the Ego of identifying self "takes the qualities of the object upon itself" (Freud, 1995, p. 263). Due to the fact that it is possible to identify with the one you love, as well as with the one you do not love, the person can also introject the qualities and motives of people, about whom the person creates very different opinions. It is common to introject an object that was lost: the loss is replaced with the introjection of the object in the Ego, which leads to the creation of such social illusions, as hope, error in perception, illusion of love and understanding, etc.

Introjection is the simplest type of internalization and its main trait is the fact, that the qualities and motives of the other are built in the structure of subject's personality without any psychological processing, i.e. without being changed. Such introjection, together with projection, may become the basis of deep and permanent identifications, common in pre-school children and, partly, in adolescents and elderly people.

As a mechanism of social illusions, introjection is unconscious and primary focuses on overcoming frustration. We suggest that the mechanism of introjection begins to work after deep personal deprivation, loss of a loved one or a valuable object. Because of this, this mechanism of social illusion can provide healthy social adaptation, relieve internal conflicts and deprivations of the individual.

Another mechanism of social illusions is the mechanism of self-restriction, thoroughly described by A. Freud, Yu. S. Savchenko, F. E. Vasilyjuk and other authors.

The mechanism of self-restriction consists of the following actions: when the person understands that his achievements are less significant in comparison with the achievements of other person or people, who are working in the same area, the person's self-respect suffers. In such frustrating situation many people tend to stop their activity, which, in a way, is a departure, a retreat from the trouble. A. Freud called this mechanism "Ego-restriction" (A. Freud \& Freud, 1997, p. 457). She noted, how simple and common this mechanism was, and, even more importantly, that it occurred in psychologically healthy people during all periods of personality development.

The manifestation of the mechanism of self-restriction does not necessarily include real departure. The departure frequently is only psychological, and the cancellation of the person's own activity is usually replaced by the observation of the activity of others. It can be hypothesized, that the frustrations, related to failures in competition with others, can lead to the development of passive and observant personality during the early stages of psychological development. A certain robust strategy of adaptation and lifestyle is created, which leads to stereotypic behavior and an illusion of comfort, success or, on the contrary, failure.

Such lifestyle mindset may gradually become more general: by restricting the activity in one area and one type of situations, a person slowly transfers such approach on other situations as well.

This mechanism can also be called generalized restriction. Its borderline forms may be dangerous for person's psychological and social health, because they are accompanied by low self-confidence, inferiority complex, apathy, development of the illusions of desperation, loneliness, misunderstanding, danger, hopelessness, dependence, etc.

Using the mechanism of self-restriction is justified in many life situations, because it provides circumstantial adaptation of the personality. However, this mechanism may also harm the individual, because any initial attempts in any area of activity cannot be perfect. So, many people get an illusion of desperation after the first unsuccessful attempts and frustration and abandon present activity, choosing something less hard. This is often facilitated by insensitive and unkind comments from the others, especially significant others (parents, teachers, close friends). It is hard not to agree with a common opinion, that may potential talents remain hidden because people are not able to realistically and patiently accept the inevitable imperfection of their initial attempts.

We also suggest that the decision to avoid the situation, requiring actions, can be frustrating itself and cause the 
activation of new defense and adaptive mechanisms, first of all, of rationalization. After making such choices, people begin to justify themselves and their decision, however, they often do not accept, that the main reason of their actions was the understanding of their own failure in the activity in comparison with the success of others. Rationalization is the next mechanism, which influences the development of social illusions. The concept of "rationalization" was introduced by E. Jones and then became common in different areas of science and different scientific schools (Jones, 1997, p. 28).

As a mechanism, affecting the development of social illusions, rationalization is a process, during which a person invents verbal and seemingly logical arguments for false explanation and justification of his frustrations, which manifest as failures, helplessness, privation and deprivation. Arguments for the rationalization are usually chosen unconsciously. Real motives of self-justifying process often remain subconscious, because the person "invents" false motives, arguments, creates his own illusions, required for justifying his actions, psychological states and frustrations. In our opinion, it is necessary to distinguish the mechanism of rationalization of social illusion from conscious deception, which implies involuntary motivation and person's certainty in the fact that he is telling the truth. Self-justifying arguments often use various "ideals" and "principles", high socially valuable motives and aims. Rationalization is a way to preserve personality self-respect in situations, which threaten to lower this important component of one's self-concept (Sokolov, 1999, p. 35).

Mechanism of rationalization is common in both individual and group social illusions. It is widely used when the person is already frustrated, for example, if he has already overstepped the conventional boundaries and, being more or less socialized, is now suffering from internal conflict or cognitive dissonance. This type of rationalization is called current rationalization, because it is required to relieve the frustration of current event. However, we think that a person can predict and foresee the occurrence of frustrating situations. This prediction of a conflict may motivate the illusions to unfold in the person's mind. For example, in individual illusions the mechanism of rationalization is used as an act of self-excuse, self-defence of the individual, his self-respect, positive self-image and the desire to preserve this image in front of himself and significant others. We also suggest that this mechanism interacts closely with mechanisms of identification and introjection; together they allow social illusions to become a united defense and adaptive construct.

A separate type of rationalization is another mechanism of social illusions, which is referred to as idealization of self, others, certain social events, feelings, etc., which also causes the development of various false ideas. For example, a young person in love creates his own illusion, which helps him to believe, that his loved one is the "only one", the most beautiful and wonderful creature that has ever existed.

Along with idealization of the other, idealization can also be directed at oneself, which is a type of narcissism. It can be common in almost everyone, but it is important that it remains healthy-the person should be able to look at himself from others' perspective and should create as few illusions about himself as possible. The mechanism of idealization may be a basis for a large group of social illusions and, first of all, for individual, interpersonal, internal, historical illusions, illusions of knowledge, etc.

Another mechanism of social illusions development is the mechanism of projection. In primitive communities, before the invention of writing, the rational practices were weak and projection mechanisms defined the human perception of the world. This mechanism implies, that certain thoughts, feeling, desires, which the person denies in himself, are attributed to other people, groups and cultures, which leads to the development of different social illusions and mistakes. For example, not being able to accept himself as envious, greedy, mean and jealous, a person transfers these qualities onto the people, who are the victims of his prejudice, thus creating an illusion of self-deception. In other cases the refusal to admit one's own tendency to act violently might lead a person to creation of an illusion of the world filled with mean images. It is also possible to define a certain "projective" mechanism of a culture, which appears in order to relieve the stress in the society and the mind of a single person, to "help" the person live in illusions.

Mechanism of projection vividly appears in festivals, carnivals, etc., i.e. through the culture, where the reality is mixed with imagination and utopia. Projection is based on strong unsatisfied needs. Projection is the reason why many people perceive the reality the way the want to see it or the way that is useful for them to see it. Mechanism of projection, underlying some social illusions, may be profitable to a certain extend. For example, the projections, underlying historical illusions, allow a person to perceive large historical events as personally significant large historical events, such as wars, revolutions, historical periods and movements, by creating an illusion of being included in that historical event or period. This helps to understand historical events better and study them more thoroughly, because another historical period is easier to understand if a person projects his own feeling onto it. Mechanism of projection also creates a poetic illusion, which lets a person to understand the 
nature deeper and more graphical, to see the nature as gloomy, happy, angry, mysterious, and calm.

On the other hand, the expansion of projective mechanisms beyond conventional social regulations leads to the occurrence of various group psychoses. For example, an image of an "internal enemy", "invader", "spy", which appears somewhat spontaneously, with the help of projection might become a justification of different actions of the government. Thus, the mechanism of projection has various influence on the development of social illusions. We suggest that this mechanism underlies historical and political illusions, cultural and artistic illusions and has a large impact on manipulation of mass conscience, for example, through art, mass media or politics.

Another significant mechanism of social illusions development is transference. This mechanism is common in suggestive and sensitive people, whose primary goal is to maintain the relationships with significant others and to analyze the event or the situation.

Transference is the mechanism of social illusions development, which implies, that an emotional value of a feeling towards one idea or person is transferred to the other idea or person. This emotional meaning or feelings may not always be adequate, therefore, the illusions, based on the transference, may also be both adequate and not. This mechanism can be a basis for interpersonal and historic illusions, perceptual illusions, etc.

Conscious mechanisms of social illusions, in our opinion, include fantasy and daydream. Fantasy is a reflection of the reality in some new, unexpected and unconventional combinations and connections. It is a creative force, which unites immediate feelings of a person with the reality, and it is a necessary element of creative activity, which presents in creation of various images and plans of actions, usually in problematic situations.

Fantasy is the creation of something that had not yet occurred in person's experience, that the person had not yet encountered and perceived. However, everything new that was created by the imagination is always, in one way or another, connected to something real.

All fantastic images are built from the material of past perception and stored memories. The fantasy is always the processing of the information from sense and perception. The fantasy cannot be created from "nothing" (e.g., innately blind person cannot create an image of a color and innately deaf person - an image of a sound). The most bizarre fictional constructs are always built from the elements of reality.

Fantasy is one of the fundamental human characteristics. It vividly demonstrates the differences between humans and their animal ancestors. "The fantasy itself, or the power of imagination, is not only highly valuable, but is also general, universal skill, which distinguishes a human from an animal. Without the fantasy not only the art is impossible... Without the power of imagination it would not even be possible to cross the street in the traffic. Without fantasy, humankind would never have sent spaceships into space". D. Diderot exclaimed: "Imagination! Without this quality one cannot be a poet, or a philosopher, or a smart person, or a thinking being, or just a human... Imagination is a skill to activate images. A person, completely lacking imagination, will be a fool" (Dederot, 1926, p. 215).

With the help of a fantasy, a person reflects the reality, but in different, unconventional and often unexpected connections and combinations. The fantasy changes the reality and creates new images, which are often illusions.

Person's fantasy can be tool to create images, that, on the one hand, help programming the activity, and on the other hand, can inhibit that activity by creating various illusions and deceptions (Eldin, 2007, p. 167; Mizonova, 2013a).

The first, and probably the main, goal of a fantasy is to allow imagining a result of an activity or social behavior of a person, imagining them not only as a "final product", but their intermediate products and components, i.e. the fantasy as a mechanism helps a person to navigate, creates a model of "final" and "intermediate" results.

Fantasy appears in case of a problem, controversy, when it is necessary to find new solutions. The fantasy is motivated by the personal needs, which can be differently arranged (adequate and inadequate, biological, social, etc.) (Mizonova, 2013b).

Fantasy may be passive and involuntary, as well as voluntary. Voluntary (active) fantasies can be divided into reproductive and creative - and the latter is the mechanism of conscious social illusions in interpersonal relationships, art and politics (Mizonova, 2010).

Another conscious mechanism of social illusions is a daydream.

Fantasies are not necessarily immediately fulfilled in real actions. On contrary, this process frequently becomes a special form of internal activity, which includes the creation of an image of desired action (Mochalov, 2006). Such images of desired future are called daydreams. Daydream is always directed to the future, to the personal 
life and activity perspectives. It allows to plan the future and to organize one's behavior in order to complete these plans. A person would not be able to imagine the future (i.e. something that is not yet here) without the imagination and the ability to build a new image. Thus, we hypothesize that, on the one hand, the daydream stimulates the development of individual and society, because each new achievement is a fulfilled dream. On the other hand, images of desired future create multiple illusions, both personal and social. When a social or personal daydream is not fulfilled, it becomes an illusion.

We also describe general mechanisms, underlying conscious and unconscious social illusions. There are the following mechanisms: combination, agglutination and emphasizing.

Mechanism of combination is the connection of separate elements of different images into new, unexpected combinations. It is not a simple summation of already familiar elements, but rather a synthesis, which creates a new image or an idea.

Agglutination - a sub-type of combination - is a mechanism of connecting, "gluing together" of different and usually independent qualities, characteristics and parts. This mechanism, which provides the development of illusions, is most common in illusions of art, politics, love, etc., and is similar to exaggeration, which is common for social illusions and tends not only to increase or decrease the qualities, but also to change or displace them.

\section{Conclusion}

We also describe a mechanism of emphasizing, i.e. highlighting of certain qualities and characteristics of personality or of different aspects and parts of a certain social event (Shukshina, 2008). Emphasizing presents in several actions: firstly, it is exaggeration or conscious accentuation of a quality, characteristic of a social event, personality trait, external image details; secondly, it is increase or decrease of a quality or an event; thirdly, it is classification, which implies generalization and emotional saturation of an image, a quality or an event (Shukshina, 2007). This persistent emphasizing of the significant and repeated details in homogeneous facts and their representation in a single image or social event may also be a mechanism, which affects the development of social illusions.

\section{References}

Barelds, D., \& Dijkstra, P. H. (2011). Pieternel Positive illusions about a partner's personality and relationship quality. Journal of research in personality, 45, 37-43.

Didro, D. (1926). Izbrannye sochineniya (Vol 2, T. 2, p. 215).

Eldin, M. A. (2007). Sud'by russkogo religioznogo tradicionalizma v prostranstve rossijskogo obschestva (p. 162). Saransk: Izdatel'stvo Mordovskogo universiteta.

Fletcher, G. J., \& Kerr, P. S. (2010). Source Through the Eyes of Love: Reality and Illusion in Intimate Relationships. Psychological Bulletin, 136, 627-658.

Freyd, A., \& Freyd, Z. (1997). Detskaya seksual'nost'i psihoanaliz detskih nevrozov (p. 457).

Freyd, Z. (1992). Psihoanaliz. Religiya. Kul'tura (p. 127).

Freyd, Z. (1995). Vvedenie v psihoanaliz:Lekcii (p. 263).

Gubskiy, E. F. (Ed.). (2009). Filosofskiy enciklopedicheskiy slovar' (p. 206). M. INFRA-M.

Heine, S. J., \& Buchtel, E. E. (2009). Personality: The Universal and the Culturally Specrfic. Book Series: Annual Review of Psychology, 60, 369-394.

Jones, E. (1997). Zhizn'i tvoreniye Z. Freyda (p. 28).

Mizonova, O. V. (2010). Duhovnost' Rossii i virtualistika. Genezis kategorii virtual'naya real'nost': Materialy mezhdunarodnoy nauchnoy konferencii (pp. 50-54). Saransk.

Mizonova, O. V. (2013a). Sovremennoe rossijskoe obschestvo respubliki Mordoviya i russkoe duhovnoe nasledie. Gumanitariy: Aktual'nye problemy nauki i obrazovaniya, 4(24), 45-49.

Mizonova, O. V. (2013b). Nravstvenno-psihologicheskie cennosti lichnosti i morali sovremennogo obschestva. Sborniki konferenciy NIC Sociosfera, 53, 99-103.

Mochalov, E. V. (2006). Antropologiya vseedinstva v russkoy filosofii. Izdatel'stvo Sankt-Peterburgskogo universiteta.

Raygorodskiy, D. (Ed.). (2006). Samosoznanie i zaschitnye mehanizmy lichnosti: Hrestomatiya. Samara.

Shukshina, L. V. (2007). Social'no-psihologicheskie faktory, vliyajuschie na razvitie social'nyh illjuziy. Vestnik 
Tambovskogo universiteta "Seriya: gumanitarnye nauki”, 6(50), 120-125.

Shukshina, L. V. (2008). Filosofskoe ponyatie, struktura i funkcii social'nyh illjuziy. Vestnik Tambovskogo universiteta "Seriya: Gumanitarnye nauki", 2(58), 296-301.

Snook, B., Cullen, R.M., \& Bernell, C. (2008). The criminal profiling illusion-What's behind the smoke and mirrors? Criminal justice and behavior, 35, 1257-1276.

Sokolov, E. V. (1999). Vvedenie v psihoanaliz: Sociokul'turnyi aspect (p. 35, p. 123).

\section{Copyrights}

Copyright for this article is retained by the author(s), with first publication rights granted to the journal.

This is an open-access article distributed under the terms and conditions of the Creative Commons Attribution license (http://creativecommons.org/licenses/by/3.0/). 